\title{
VIRTUES IN DANISH HISTORY TEXTBOOKS SINCE ENLIGHTENMENT
}

DOI: http://dx.doi.org/10.17159/2223-0386/2018/n18a1

\author{
Harry Haue \\ Department for the Study of Culture \\ University of Southern Denmark, Odense, DK 5230 \\ hh@sdu.dk
}

\begin{abstract}
Beaten down, sickly, virtue has now been allowed to enter in all its tatters and sit in the corner, as long as it doesn't raise its voice
\end{abstract}

(A Solzhenitsyn, The Gulag Archipelago. London, Collins/Fontana, 1974, p. 175)

\section{Abstract}

The above quoted statement by the famous Russian author, Alexander Solzhenitsyn, can to my opinion be interpreted as a dream of revitalization of good, old Russian virtues, which the communist regime had silenced and placed in the corner. Then I reflected on the status of virtues in my own country, and especially what history education had done to stick to virtues, which I have encountered in my earlier research as dominant in the $18^{\text {th }}$ century educational discourse? My provisional examinations are presented in this article, where I focus on the impact of virtues in a sample of more popular Danish history textbooks over three centuries.

Research in textbooks is closely connected to the societal context and a brief summary of the development in Denmark since the Enlightenment is appropriate, especially for the foreign reader, in order to understand the textbooks in a proper context.

In the $18^{\text {th }}$ century the Danish king was the absolute ruler of Denmark, Norway and the North Atlantic islands. Moreover he was the sovereign in the deuces Schleswig and Holstein and of course in the colonies in India, Africa and Caribbean. This multicultural state was transformed in the $19^{\text {th }}$ century; in 1814 Norway was ceded to Sweden, and in 1864 Schleswig and Holstein were after a bloody war, taken over by Prussia. Hence Denmark was one of the smaller countries in Europe, however now a national state. In 1814 compulsory sevenyear school attendance was implemented for all girls and boys, and in the second half of the century agriculture and industry underwent a remarkable growth. In 1849 the absolute ruling king signed a constitution, which introduced partial democratic elections. Although literacy was acquired by nearly all Danish children, the development of secondary education was slow, illustrated by the fact that only 89 students in 1849 finished their upper secondary education in the Kingdom of Denmark. In 1921 it rose to nearly 2\% of a year group, whereas today 75 $\%$, equivalent to 60.000 teenagers are prepared for further studies. The upper 
secondary education also consisted of lower secondary schools, which prepared the students for trade and public services.

Over the three centuries history education was mandatory for all upper secondary students. In this article I shall give some provisional answers to the questions: What happened to virtues in history textbooks over 300 years and why?

Keywords: Virtues; History textbooks; Ethics; Moral; Historical consciousness; Anthropocene era.

\section{Introduction}

My former examinations of Danish history textbooks from the $18^{\text {th }}$ Century showed that theywere focused on virtues; however in the $19^{\text {th }}$ and most of the $20^{\text {th }}$ century, it is my assumption that the emphasis on virtues were weakened, most likely under the influence of the positivist scientific approach to the rendering of the past. In the closing decades of the $20^{\text {th }}$ century, philosophers reintroduced the concept of virtues as an appropriate way to cope with the overarching challenges in the late modern society. In the beginning of the 21 st century a new moral and ethical attitude seems to be emerging - and this raises my research question: Are the modern history-textbooks influenced by the modern philosophy of virtues?

My empirical material consist of five history textbooks from respectively 1777 , 1858, 1893, 1985 and 2008 which were widely used in secondary schools. In this article I have chosen two topics for examination: The introduction of Christianity in Denmark during the Viking era and the exposition of the Danish slave trade. These two topics have been selected because of their inherent moral /ethical content, which might inspire historians and authors of history textbooks to focus on this aspect.

The theoretical framework is a modified discourse theory which focuses on interdiscursivity. For a methodological tool I use the rhetorical pentagram. (Viby Gymnasiums skriveportal, n.d.), which was reinvented in the 1980s as an imitation of the model made by Marcus Tullius Cicero in the last century BC. The five points, which all are in correspondence with each other, i.e.: topic, sender, receiver, circumstances and language. These points and the connections between them make the pentagram a useful model also for the comparison of history textbooks in a diachronically manner.

\section{Virtues - from Aristotle to McIntyre}

The classical concept of virtues was still dominant in the Enlightenment era 
and the Aristotelean understanding of those virtues was, in the $18^{\text {th }}$ century, a guideline for many authors of history textbooks. For example, the highly respected $18^{\text {th }}$ century Danish author, Ludvig Holberg (1684-1754), wrote a widely used schoolbook in Latin in which he stated: "History is a narrative about the past, which aims at maintaining the memory of the events, from which we may deduct learning that leads to a happy life" (Holberg, 1749:2). But what are virtues? Aristotle (384-322 BC) has in his writings: The Nicomachean Ethics discussed the concept of Eudaimonia (happiness/flourishing) and examined the concept of areté (virtue/excellence) and concluded that if we use reason well we live well as human beings (Kraut, 2018). The Aristotelian concept of virtues in the late Enlightenment period was challenged by two other concepts: the utilitarian understanding of the good life and the Kantian concept of duty. The utilitarian thinking was advocated by, among others, John Stuart Mill (18061873) whereas the duty-based understanding of the good life was formulated by Emmanuel Kant (1724-1804). These two concepts placed virtues in the shadow for a long time. However, in the 1980s the Scottish philosopher Alasdair McIntyre attempted to revitalizes the concept of virtues (McIntyre, 1981). His main argument was that virtues made it possible to understand the modern complex world in a more comprehensive way and make each person responsible to contribute to solve the global challenges. Virtues can be defined as personal traits or qualities that are deemed to be morally good and thus are valued as the foundation of principle and of moral being. There are at least four classical virtues: Temperance, Prudence, Fortitude and Justice. Together with the three Christian of virtues of Faith, Hope and Love they form the seven cardinal virtues.

Since Cicero translated the Greek concept of ethics into Latin as moral a discussion is ongoing as to the relationship between the two concepts. In this article I shall treat them as equal. However in relation to virtue I understand this concept as overriding in relation to ethics and moral.

\section{The selected textbooks}

Ove Malling (1746-1829) placed Christian religious virtue in the first chapter of his textbook from 1777: Great and Good Deeds by Danes, Norwegians and Holsteinians. In his foreword Malling wrote about the blessings of virtues:

However, it is not sufficient for the monarch to encourage the now living generation. Future generations should also be acquainted with the virtues of their forefathers which would thereby become the virtues of the country and the throne, as with the former generation... These virtues should be researched, collected and 
told. It should be easy for the young generation to know them, to take note of them and to value them (Malling, 1777:3).

Malling's textbook was sponsored by the king's government, formally presided by the insane king Christian VII, in connection with a reform of the grammar school, which was to put more emphasis on teaching in the mother tongue (Danish) and on the history of the fatherland. The aim of this reform was to develop patriotic virtues. Malling's book was translated from Danish into English in 1807 and later into French and German.

In the 1840s Malling's book was gradually replaced by CF Allen's Reader on the History of Denmark, which adopted a nationalistic approach. Consequently the history textbook functioned as a tool in the nation building process. In the preface Allen (1811-1871) underlines that the textbook is written in an easy understandable language, which he meant was a precondition for its use in schools (Allen, 1858:2).

At the end of the 19th century a new type of history textbook became popular. It was written in 1893 by a progressive politician, Johan Ottosen (1859-1904), who had a scientific positivist attitude to the teaching of history in schools. In 1849 Denmark had a partial democratic constitution and his History of the Nordic Countries claimed to replace the nationalistic attitudes of former textbooks and to focus instead on a Pan-Scandinavian view with an emphasis on people's everyday lives. This textbook dominated upper secondary history education for three quarters of a century, from 1893 to 1968 . However, new editions were written by other historians as Ottosen died in 1904. After a reform of the upper secondary school in 1935 it became mandatory to include source material in a couple of topics, which enabled the students, guided by the teacher, to draw their own conclusions. From 1900-1935 Ottosen's textbook was used by $85 \%$ of classes in Denmark (Møller, 1983:140).

After 1973, when Denmark (but not Norway, Sweden or Finland) joined the European Community, the next history of Denmark, The old Denmark (Haue, Olsen \& Aarup-Kristensen, 1985), placed the national history in a European context. Emphasis was on the economic, democratic and social development with open questions to encourage discussions in classes.

By the turn of the millennium the global discourse inspired both the syllabus writers and textbook authors to integrate the national and European development within a global history. One of the most popular texts was written by Carl-Johan Bryld (2008). Apart from combining Danish and world history, The world before 1914 - from a Danish perspective had an interactive 
online supplement which included working questions. In the preface the author stresses his hope that each chapter could inspire discussions in classes. The Danish history textbook was now transformed into a global agent with a reflexive aim (Bryld, 2008). Having presented the chosen history textbooks, I shall continue my examination of the textbooks. The focus will be on (a) the introduction of Christianity in Denmark in the Viking period (750-1050) and (b) on the Danish participation in the Atlantic slave trade. The two topics have been chosen because of their potential moral/ethical content.

\section{Malling on religion and the slave trade}

Ove Malling, a well-educated Danish polyhistor, begins his first chapter with a bombastic dictum: "Religion is the mother of all virtues". He explains: "Man only needs to see, think, and feel in order to be sure that God exists, who has created all things and governs them" (Malling, 1777:1).

The author follows the Aristotelian concepts of virtue: "if man is able to think and feel in the right manner, nothing is more important for him than to know God's will and laws". According to Malling the Christian religion presupposes prayers and obedience. Malling presents different personages (kings, noblemen and the clergy) to illustrate his points. An Icelandic Viking realizes that the heathen gods, Wotan and Thor, were insufficient so he turned to Christianity for salvation. So did the English-Danish king Canute the Great for whom the most important task was to safeguard true religious worship. Malling tells of Canute's wisdom and humble attitude towards God. He stressed that: "Knowledge about Religion is the foundation of true wisdom and the sense of religion is the foundation of true virtue" (Malling, 1777:8).

In the $17^{\text {th }}$ century the Danish monarch, Christian IV as part of a mercantile culture, founded companies and bought trading stations in India and, later colonies in the Caribbean and Africa. This trading gradually came into conflict with the Enlightenment attitudes of natural human rights. Malling, as a loyal servant of the king had to balance the ideas of mankind's equality with the fact that thousands of Africans were caught, sold and transported to the Caribbean plantations. Malling solves this paradox by writing about how the African slaves were oppressed. "One got used to seeing human beings as slaves and slaves as dumb animals. One has bought them and sold them and generally treated them with harshness, which bestows on the cultivated Europeans little honour. Our Danish merchants cannot be said not to have taken part in this violence" (Malling, 1777:43). 
However, in order to balance the Danish participation in the slave trade, Malling describes two Danish civil servants, Christen Cornelisen (1661) and Severin Schilderup (1735) who treated the African slaves with kindness. They regarded them more as friends and each behaved more like a father than a merchant. Consequently the African slaves loved them and some even named their children after them. When the two civil servants were called back to Denmark there was widespread sorrow.

Malling finishes his description thus: "In those years when the two civil servants ruled on the Danish part of the Gold Coast, the trade was so profitable that it was difficult to import a sufficient amount of merchandises from Denmark to meet the demand" (Malling, 1777:46).

So trade prospered; the slave trade flourished. On the one hand Malling could not condemn the slave trade, which would have caused problems with the government. But on the other hand he tried to show that this trade could be managed in a humane way. The role model for the students was the loyal and decent civil servant, who makes a virtue of necessity.

Virtues were Malling's main focus when writing the history of Denmark. The young historian was loyal to king and government and determined to influence his young students to internalize the virtues in question. The language was adapted to boys' fascination with the deeds of dutiful and courageous Danes, Norwegians and Holsteinians. The aim was the patriotic upbringing and socialization of the future Danish elite. The interplay between the five points in the rhetorical pentagram gives a comprehensive understanding of the intentions and power of penetration of this textbook.

\section{Carl Ferdinand Allen - the nationalistic propagator}

In 1836, half a century after the publication of Malling's Great Deeds, The Society for the right Use of the Liberty of the press, organised a competition on the writing of a history of Denmark, focusing on the relationship between the state and the people. The society was a liberal political body, whose members dreamt of a constitution which would restrict the power of the absolute monarch. A young historian, CF Allen (1811-71) won the prize and published his Handbook on the History of the Fatherland with special emphasis on the development of the people and the state's interior progress (Allen, 1840). In 1843 the book was edited as a school textbook: Reader on the History of Denmark. In this article I have used the 8th edition (Allen, 1858). This textbook dominated history education in the second half of the $19^{\text {th }}$ century (Haue, 2006:23). 
Compared to Malling, religion played a different role in Allen's book, in which the Christianization of the Nordic countries is presented from a totally different perspective. After a long and well-informed description of the ancient history of Denmark, Allen gives an account of the changes in religion. It was about 200 years from the first missionaries' arrival (around 800 ) before Christianity was accepted as the people's religion. Although the king, Harold Bluetooth was baptized in 965, Allen focused on the people, who were reluctant to accept the new faith. The author explains this by pointing out that the Scandinavian people lived a wild and harsh life as Vikings, often solving conflicts with the sword. Christianity forbade single combat, along with suicide, polygamy, the eating of horse meat and work on Sundays. Instead, the Norse people were now expected to see themselves as sinners who had to do penance. Moreover, the church was against slavery and demanded the payment of tithes. In return for giving up their traditional way of life the Norse people were told about Jesus Christ, a peaceful God, who promised them an afterlife in paradise instead of in Valhalla, where drinking, fighting and sexual activities were believed to take place.

Allen argues that Christianity stood in sharp contrast to the traditional Norse way of life, which was founded on a free peasant community and with its values shared by all Scandinavian people. This point of view was undoubtedly influences by the new Pan-Scandinavian movement which promulgated the ancient Norse history, documented in burial mounds and the Icelandic Sagas. But even Allen had to concede that Christianity was more advanced than the Norse mythological conception. Nonetheless the consequences for the peasants were hard; the Catholic Church supported the nobility, which afterwards suppressed the former free peasants. However, the fascination with the Pre-Christian life could inspire the students to cherish a renaissance of the old Nordic ideals of freedom and equality compatible with the visions of a new democratic nation.

The consequences for the teaching of history were fundamental. The nationbased concept of history was to be understood more by the heart than by the brain. Rote learning was either supplemented by, or substituted with engaging narratives. This glorification of the Nordic past was disseminated in the many folk high schools, and in literature. In the preface to his schoolbook he wrote that his intention was to arouse and nourish the student's national mind and way of thinking. He did not use the term "virtue"; however his description of the history of the fatherland was constructed to serve his idealistic liberal 
political visions. Ranke-inspired historians opposed Allen's description of the pre-Christian period as idealistic and not compatible with the source material (Morhorst, 2005:137).

Allen's description of the slave trade is short an empathetic: "The Danish government's very positive indication of the humane values by which it was led by banning the Negro trade earlier than has happened in any other European state" (Allen, 1858:200). He refers to the Danish Governments ban on the slave trade in 1792. He did not speak of virtue, however the use of "humane values" could to my opinion be understood as an equivalent expression. Although the 8th edition of the Reader was published 10 years after Denmark's ban on slavery, this is strangely not mentioned. The syllabus of 1850 indicated that the national history should be upgraded. It was important that the small Danish elite became part of the nation building process.

Allen's textbook shifted the focus from patriotic to nationalistic attitudes and the main topic was not religion, but folk, language and nation. Norway was ceded to Sweden after the Napoleonic Wars in 1814, and Holstein wanted to be governed by Germany. As a young national-liberal Allen wanted a fatherland with a homogeneous national composition. Students were expected to learn to love their fatherland and, in that, history education had an important role to play. At the time Denmark was predominantly agrarian and the peasants were the backbone of the new constitutional nation; therefore it was important to give them a sense of a lost freedom and equality, which could be regained, albeit on a dubious interpretation of the past. The history text books used in the upper secondary school became a model for the teaching of history in the primary school.

Summarized according to the pentagram, the author formed his description of the history of Denmark with a certain aim: Nation building, which the coming Danish elite should internalise and communicate to the people: mainly the peasant community. The language in the textbook was adapted to the intended reader: Teenage boys, who were supposed to be brought to love their fatherland.

\section{Nordic History by Ottosen 1893}

At the end of the $19^{\text {th }}$ century Allen's textbook was gradually replaced by Nordic History, written by Johan Ottosen (1859-1904), a historian educated at the University of Copenhagen and a liberal member of parliament. Ottosen's approach was labelled as progressive and scientific. In the first edition of Nordic History (published in 1893) he pretended to focus on the life and culture of 
the common people instead of on wars and big-politics, and included all the Nordic countries. In contrast to Malling and Allen he replaced their idealistic political views with a scientific approach. The new French and German positivist thinking influenced his description of the religious changes during the Viking period. One of his university professors had studied in Berlin and became familiar with the new method of source critics, which also brought a paradigmatic change to history research in Denmark. The new buzz word was borrowed from Leopold von Ranke: "wie es eigentlich gewesen” (Ranke:1824, Vorwort).

Ottosen was thus opposed to the uncritical use of source material such as the writings of Saxo Grammaticus and the Sagas, which both were written in the beginning of the $13^{\text {th }}$ century, two centuries after the end of the Viking era. He relied more on archaeology and European contemporary source material, for example Annales Francorum. Religion in the Viking period, according to Ottosen, should be understood as a dual system, where the warrior upper class believed in Wotan and Thor and the other Asa gods, whilst the peasant majority was convinced that deities lived in rivers, woods, burial mounds and barrows. Christianity was mainly accepted by the warrior class, which had experienced Christian societies on their raids to England and France. According to the author the peasants, however, for centuries continued to worship their local elf-hills and the like.

Against this background it is understandable that the Nordic view of the past came to influence the syllabus for history teaching. In 1906 Danish history was changed to Nordic history and mother tongue teaching included knowledge of Norwegian and Swedish languages and, up to 1935, some insight into the old-Icelandic language. It was argued that the Danes had more in common with our northern brothers than with the rest of Europe, a conception which dominated until 1973 when Denmark became a member of the European Community (Haue, 2014:83).

Ottosen describes the ban on the slave trade in connection with other reforms: "It was not only in relation to the peasants of the kingdom that the government sought to remove the inequality and inhumane conditions of the past. The Jews gradually were given full citizens' rights. Serfdom was abolished in Holstein and the southern part of Schleswig. Finally Denmark was the first state which forbade the Negro trade" (Ottosen, 1893:216). Compared to the textbooks of Malling and Allen the textbook of Ottosen used a scientific language and had a source critical attitude. This language had 
at the time no room for virtues, although the authors were sympathetic to liberal, democratic reforms.

Ottosen's textbook had a long life in the Danish upper secondary school and, after his death in 1904 other historians were engaged to continue its publication. The syllabus emphasized objectivity in accordance with positivist attitudes in academia. The aim was to develop the students' scientific thinking and a sense of a Nordic commonwealth.

In short Nordic History was a well-written and illustrated textbook, which in a scientific way should convince the students - now also, the girls - of the values of Nordic cooperation and thereby inspired them to develop a Nordic cultural identity. No mentioning of virtues, however the textbook included certain values, which could strengthen the democracy and an objective understanding of the historical development.

\section{Denmark in Europe 1973}

During the1970s the argument for a Nordic history in schools was fading and the focus changed to Danish history with its European relations. The Old Norse mythology was no longer understood in a regional setting. However, research proved that Wotan was originally an Asiatic god and that many elements in Nordic Pre-Christian mythology were borrowed from Europe. For example, The old Denmark (Haue, Olsen \& Aarup-Kristensen, 1985) used a scientific description of the change of religion in the late Viking age, without any moral preferences or arguments. The three authors all had a university degree in history. The old Denmark states:

Behind the multifarious number of gods, it is possible to detect a three form structure, which is common among Indo-Europeans i.e. among Europeans and people from Asia Minor and India, who have common language roots: Authorityruler good, mystique, magic, knowledge, Wotan. Strength - martial good, defence against enemies, Thor. Fertility - production, provision, Frey. Therefore there was no reason to consider Nordic Religion as something originally Nordic, but the result of influences over several centuries from very different places (Haue, 1985:46).

This scientifically based description emphasizes political and strategic explanations for King Harold Bluetooth, who in 965, wanted to be baptized. However, there are no moral or ethical connotations and no mention of virtue. Secularization and internationalization have, of course, helped to reduce or even to remove from the Danish history textbook moral and ethical questions when it comes to religion. But the students were supposed to study source 
material, which could conflict with the views put forward in the textbook.

The authors (Haue, Olsen \& Aarup-Kristensen) of The old Denmark mention the abolition of the slave trade in neutral terms, without stating that Denmark was the first state to do so. Alongside the text an illustration depicts the enslavement of the Africans and the harsh treatment they were exposed to. However, at the end of the chapter the authors open up the discussion of the principal forces at work in the past. In a counter argument a liberal and a Marxist view are presented - the former from a humanist perspective whilst the latter focuses on the capitalist mode of production. Against this background the students could discuss the issues on a higher level, a systemic meta-level, which also might include their own moral and ethical attitudes. This technique gave the students an opportunity to develop their own ideas and not, as was common in the positivist era, just to reproduce the textbook. Since 1971 the syllabus gave the students a right to decide together with the teacher, which topics they wanted to work with and how the lessons should be organised.

Although, in the last decades of the 20s century, the textbook still had a vital role to play in history teaching in Denmark, supplementary material was widely used. Chronology was not seen as important and neither was the earlier wish to pursue scientific objectivity. Conclusions were arrived at in class after discussion and documentation. The new textbook became part of this dialogue and was now as much source material as many other types of texts. The aim was to develop the students' powers of reflections in connection with the multi-perspective organization of the subject matter. Moreover, it was considered important that the students saw themselves as both produced by history and co-producers of history, developing what became the buzz-word in history didactics as "historical consciousness" (Haue, 2007:71).

If The old Denmark is related to the rhetorical Pentagram the aim was not - as in Ottosen's textbook - Nordic but European; the language was still scientific, although the didactical aim now was a dialogue in classes. The new textbook was not a key to learn by heart, moreover the textbook was one opinion among other sources. The students in the upper secondary school grow from $10 \%$ of a year group in 1960 to $25 \%$ in 1985 .

\section{Bryld 2008}

Carl-Johan Bryld, in The world before 1914 - from a Danish perspective (2008) which is widely used in the upper secondary school, has a description of the Viking expeditions to England and France and the introduction of Christianity 
in Denmark. The author writes of the baptizing of Harold Bluetooth in 965 and of the reign of Canute the Great (who was also King of England from 1017-35): "Canute the Great appeared as an influential Christian, medieval ruler. Denmark was now a part of Christian Western Europe and the Viking expeditions ended" (Bryld, 2008:74).

Bryld presents a thorough discussion of the slave trade and the triangular trade system. He writes:

Also Denmark established and fortified slave trade stations on the Gold Coast of Africa, what today is called Ghana, in 1658, and in the West Indies three sugar producing islands were acquired, St. Thomas, St. Jan and St Croix...Many historians have emphasized that the slave trade had a destructive impact on Africa. African society was drained of its work force and consequently was disorganized because of the efforts of chieftains and tribes to acquire slaves for sale. There were, however, not very many Europeans who questioned the legitimacy of the slave trade. The Europeans were convinced that the intelligence of black Africans either had a totally different nature to that of the white man, or it was at least much inferior. The argument was that the slaves were taken by Africans in Africa. Those who sold their children ought - according to the understanding of the Europeans - to be condemned, rather than the buyer. Racism was taken for granted (Bryld, 2008:175).

Denmark's abolition of the slave trade in 1792 is mentioned as is the fact that many voices criticized the cruel way the slaves were treated on the ships and on the plantations. The text is accompanied by a drawing from 1680 depicting negotiations on the African coast between the European slave traders and the chieftains who deliver the slaves in exchange for money and merchandise. This highly moral and ethical description could inspire a class discussion and even help to form the student's virtue in an Aristotelian way - that is, acquired by knowledge and a moral/ethical approach, as in the Enlightenment era. Bryld presents the reforms of the Enlightenment thus: "The adherents of the Enlightenment criticized the barbaric and cruel corporal punishments, which were common at the time. Many crimes were punished by death and, in some cases the condemned was exposed to terrible torments before the execution. Flogging was common and so was branding, which forever would expel the condemned from society" (Bryld, 2008:194). The people who supported the Enlightenment attacked the use of torture to procure a confession, "All that was an expression of an obsolete, primitive and brutal way of thinking" (Bryld, 2008:194). This text could lead the class to discuss moral and ethical aspects of the past, which might contribute to the formation of virtues like those from the $18^{\text {th }}$ century. 
If Bryld's text is related to the rhetorical pentagram, the two topics: Introduction of Christianity in Denmark and the Danish slave trade makes it possibly to make a systematic comparison of this book to the four others. The author treats Canute as an influential Christian, medieval ruler, and that he managed to make Denmark a part of Western Europe. Compared to the four other textbooks, an interdiscursive examination shows that the European perspective is more predominant. The readers must be supposed to take an interest in acquiring knowledge of the first relation at a state level between Denmark and Europe. The syllabus from 2005 indicates that the national history should be seen in a broader scope (Haue, 2007:76).

The author's treatment of the Danish slave trade has many moral/ethical considerations, and refers to the white man's prejudices to the African populations. This empathetic view on the attitudes on the slave trade makes it possible for the students to reflect on the differences between then and now. Compared to the former four textbooks, which are parts of this examination, the moral/ethical attitudes in the text of Bryld, and the text of Malling from 1777 have many formulations in common. However Bryld does not use virtues; the explanation must be that the concept of virtue has not yet entered the language of history didactics. The similarities between the texts from 1777 and 2008 are perhaps due to a revival of virtues in the sense of McIntyre. It is in his objective necessary to make people/students aware of their commitment the global development. A tendency which can be seen in the paradigmatic assumptions of the Dutch philosopher, Paul J. Crutzen (2010), who in 2002 put forward a remarkable thesis: The earth has passed into a new epoch, the Anthropocene era, which postulates that mankind now must take responsibility for the development of the globe. Up to the 1960s the globe was according to Crutzen in another era, the Holocene era, in which nature could repair the destructive consequences of mankind's activities. This is no longer possible, thus man must in order to survive do an effort.

\section{Discussion and conclusion}

For a historian it is not surprising that each new generation poses different questions to the traces of the past than the former generation did. As already the Greek philosopher Heraclitus noted: A man does never swim twice in the same river (Kahn,1979:168). However, it is more difficult fully to explain why exactly the specific questions were asked, and why the answers are as they are. 
In this article a few questions on Danish history textbooks had been addressed, much used over three centuries in the upper secondary school. Some responses had been provided. This examination resembles a trial trench of the archaeologist. It is hoped that the research discussions and outcome will inspire further research - also in other countries.

Using the rhetorical pentagram the dominating topics were chronological presented in the textbooks: patriotism, nationalism followed by orientation towards the Nordic countries, the European scene and the global horizon. The senders, i.e. the authors of the five textbooks were all academic educated historians well acquainted with the teaching of history in the upper secondary school. The receivers/readers changed fundamentally during the three centuries from 100-400 boy-students a year before 1900. From the beginning of the 20s century girls were admitted to the upper secondary education. In 1960 the number of new students was 8000 , which rose to 24000 in 1985, and in 2012 more than 60000 students finished their examination. The Danish upper secondary school developed from elite to mass education (Haue, 2017:55, 60). In spite of the change of number of students the subject matter of history was in all three centuries a mandatory subject for all students. The language changed from the picturesque narrative to the scientific objective at the end of the 19s century. From the 1970s the textbooks were supposed to inspire to multi perspective approaches. The five examined textbooks had a variety of interdiscursivity. It is rather striking that corresponding attitudes were found in the comparisons between the textbook from 1777 and this from 2008. The virtues in the first book corresponded on the treatment of the slave trade to the ethical and moral attitudes of the later. The philosophical turn made by among others Alasdair McIntyre seem to have had some impact on the textbook from 2008, although the concept "virtue" was not reused in history didactics and history textbooks. The reason for that might be found in the moral and linguistic changes. The concept of virtue could be seen as a "flying signifier", which on the one hand could change content, and on the other hand nonetheless lose its hegemonial status in the 19s century because it did nog survive the Ranke dictum: "wie es eigentlich gewesen" (Ranke,1824:Vorwort). The conflict between virtue as a moral normative understanding of the aim with history research and teaching did not survive the new scientific paradigm. When the moral normative aim of history teaching returned in the 21 s century, the concept of virtue was seen as obsolete and difficult to use in a history textbook, albeit its revival in the philosophical world. 


\section{References}

Allen, CF 1840. Haandbog i Fadrelandets Historie med stadigt henblik paa folkets og Statens indre udvikling. København: Gyldendal.

Allen, CF 1858. Lasebog i Danmarks Historie til skolebrug, København: Reitzels Forlag.

Bryld, C-J 2008. Verden for 1914 - I dansk perspektiv. Aarhus: Systime.

Bryld, C-J 2007. Verden efter 1914 - i dansk perspektiv. Aarhus: Systime.

Crutzen, PJ 2010. Anthropocene man, Nature, 467.

Haue, H, Olsen, J \& Aarup-Kristensen, J 1985. Detgamle Danmark 800-1890. Udviklingslinjer og tendenser. København: Munksgaard.

Haue, H 2006. Forord bryder ingen trætte. In: Damberg, E et al (Red.). Litterat på eventyr. Festskrift til Finn Hauberg Mortensen. Odense: Syddansk Universitetsforlag.

Haue, H 2007. Didactics of History. Five lectures. Odense: Gymnasiepædagogik, 65.

Haue, H 2008. Allgemeinbildung. Ein deutscher begriff im Dänischen Gymnasium 1750-2007, Odense: Süddänischer Universitäts Verlag.

Haue, H 2011. History Education in Denmark. In: E Erdmann \& W Hasberg, W (eds.). Facing Mapping Bridging Diversity. Foundation of a European discourse on History education. Schwalbach: Wochen Schau Wissenschaft.

Haue, H 2013. Transformation of textbooks from national to global agent. Nordidactica, 1:80-89.

Haue, H 2014. Den danske skoles orientering. In: T Balle, H Haue \& M Schelde (red.). Nordisk pedagogisk tradition? - mellem Grundtvig og Ny Nordisk Skole. Odense: Gymnasiepædagogik nr. 94.

Haue, H 2017. Gymnasiets transformation. In: J Dolin et al (red.). Gymnasiepadagogik. En grundbog.3.udg. København: Hans Reitzels Forlag.

Holberg, L 1749. Synopsis Historice universalis Methodo erotematica exposita. Hafniæ: Henricum Berlingium.

Kahn, CH 1976. Heraclitus. An edition of fragments with translation and commentary. Cambridge University Press: London.

Kraut, R 2018. "Aristotele's Ethics" The Stanford Encyclopedia of Philosophy. Available at http:// plato.stanford.eud/archives/summer2018/entries/aristotele.ethics/, Accessed on 20 June 2018.

McIntyre, A 1997. After virtue - a Study in moral Theory, 3. Notre Dame: University of Notre Dame Press.

Møller, J 1983. Historieundervisning i gymnasiet gennem de sidste 100 år. København: Gads Forlag.

Malling, O 1777. Store og gode Handlinger af Danske, Norske og Holstenere. København: Gyldendal. 
Mordhorst, M \& Møller, JF 2005. Historikeren Caspar Paludan-Müller. København: Det Kongelige Bibliotek/ Museum Tusculanums Forlag.

Ottosen, J 1893. Nordens Historie til brug for den højere Undervisning. København: PG Phillipsens Forlag.

Ranke, L 1824. Geschichte der romanischen und germanischen Völker von 1494-1514. Leipzig.

Viby Gymnasiums skriveportal, n.d. How to read non-fiction texts (using the rhetorical pentagram). Available at http://octavius.vibygym.dk/uploads/2/9/7/7/29775175/ nonfiction-analysis.pdf. Accessed 20 June 2018. 